\title{
DEGRADASI BAHAN ORGANIK DAN PROTEIN SECARA IN SACCO LIMA RUMPUT TROPIK
}

\author{
B.P.Widyobroto, S. Padmowijoto dan R. Utomo ${ }^{1}$
}

\section{INTISARI}

Penelitian ini bertujuan untuk mengetahui degradasi bahan organik (BO) dan protein kasar (PK) secara in sacco lina jenis rumput tropik. Penelitian dilakukan dengan menggunakan 3 ekor sapi Peranakan Friesien Holstein yang difistulasi pada bagian rumennya, diberi ransum terdiri dari Pennisetum purpureum (PK $9 \%$ ) dan konsentrat (PK $17 \%$ ) dengan imbangan $70 \%: 30 \%$. Pennisctum purpureum $(P p)$, Panicum maximum (Pm), Setaria spacelata (Ss), Cynodon dactylon (Cl) dan Brachiaria mutica (Bm) diinkubasikan dalam rumen selama $2,4,8,16,24$ dan 48 jam, dan setiap waktu inkubasi diadakan 6 kali ulangan. Residu pakan setelah inkubasi dianalisis kandungan BO Jan PK. Data yang diperoleh berupa kinetik kehilangan BO dan PK digunakan untuk menghitung degradasi teori (DT $=a+b$ $* \mathrm{c} / \mathrm{c}+0,06)$ dengan model exponensial Orskov dan McDonald (1979), $\mathrm{p}=\mathrm{a}+\mathrm{b}(1-$ $\left.\exp { }^{-61}\right)$, dengan $a=$ fraksi mudah larut, $b=$ fraksi potensial terdegradasi dan $c=$ laju degradasi fraksi b dan kp 0,06 (Verite dan Peyraud, 1988). Data fraksi a, b, c dan DT dari BO dan PK dianalisis variansi dengan pola searah. Hasil penelitian menunjukkan terdapat perbedaan sangat nyata $(P<0,01)$ fraksi $a, b, c$ dan DT dari BO dan PK. Degradasi BO rumput $P p$ paling tinggi $(45,13 \%)$ dan degradasi $\mathrm{BO}$ rumput $P m$ paling rendah dibanding rumput lainnya $(33,07 \%)$. Degradasi BO rumput $S s, C d$ dan $B m$ berbeda tidak nyata (masing-nasing 40,$97 ; 39,16$ dan $40,00 \%$ ). Degradasi $\mathrm{PK}$ rumput $\mathrm{Cl}$ lebih tinggi ( $\mathrm{P}<$ 0,01 ) dibauding $P p, P m$ dan $B m$ (masing-masing 62,$25 ; 56,80$ dan $57,96 \%$ ), tetapi tidak berbeda nyata dengan rumput $S s(60,78 \%)$. Hasil penelitian menunjukkan adanya variasi degradasi BO dan PK lima jenis rumput.

(Kata kunci: In sacco, Organik, Protein, Rumput, Tropik, Ruminansia.)

Buletiu Peternakan 19: 43-53, 1995

' Fakultas Peternakan UGM, Yogyakarta 55281 


\section{IN SACCO DEGRADATION OF ORGANIK MATTER AND CRUDE PROTEIN OF FIVE TROPICAL GRASS}

(Satte

Hveip

1978

Zinn

\section{ABSTRACT}

The experiment was conducted to compare the organik matter and protein degradation of five tropical grasses in the rumen. Three adult cows weighing about 350-400 $\mathrm{kg}$, and fitted with rumen cannulae were used. They were fed at maintenance condition with Pennisetum purpureun (CP 9\%) and concentrat (CP 17\%) at ratio $70 \%: 30 \%$. Nitrogen Jegradation of Pennisetum purpureum (Pp), Panicum maximum $(P m)$, Setaria spacelata $(S s)$, Cynodon dactylon $(\mathrm{Cd})$ and Brachiaria mutica $(\mathrm{Bm})$ were studied according to the method describe by Michalet-Doreau et al. (1987) with 6 replications each feed. Nitrogen degradation kinetics were ajusted to the single exponensial model of Orskov and McDonald (1979) as follows : $D(t)=a+b(1-\exp -t)$. The effective protein degradation was calculated for $a$ rumen outflow rate $(\mathrm{kp})$ of $0.06 / \mathrm{h}$ by using thr formula DT $=a+b c /(c+k p)$. The results showed that $a, b, c$ parameters and DT of $O M$ and $C P$ were significantly different $(P<0.01)$. DTOM of $P p$ was the highest (45.13\%) and $P m$ was the lowest (33.07\%). DTOM of $S s$, $\mathrm{Cl}$ and $\mathrm{Bm}$ were not significantly difference $(40.97,39.16$, and $40.00 \%$, respectively). DTCP of $C d$ and $S s$ were not significantly difference $(62.25$ and $60.78 \%)$, however they was significantly higher $(\mathrm{P}<0.01$ ) compared others. $\mathrm{Cl}$ had the highest degradation, it might be explained by the rapilly soluble fraction. The result can be concluded that, the average of protein degradation of tropical forages had variation among feedstuff.

(Key words: in sacco, Organic, Protein, Grass, Tropic, Runinants.)

\section{Pendahuluan}

Degradasi protein pakan dalam rumen adalah parameter yang penting untuk diketahui guna mendeteksi ketersediaan rrekursor nitrogen untuk sintesis protcin mikroba. Dengan demikian degradasi protein pakan merupakan karakteristik esensiil untuk mengevaluasi kualitas protein pakan. Degradasi protein bukan merupakan karakteristik positif atau negatif dari suatu pakan, tetapi pada realisasi pembuatan ransum diperlukan gabungan bahan pakan dengan tingkat degradasi protein yang berbeda untuk mengoptimumkan produktivitas lernak.

Evaluasi kebutultan protein "modern" untuk ternak ruminansia didasarkan pada ketersediaan asam amino (AA), tergantung dari protein tercerna dalam usus halus dan absorbsi dari AA tersebut. Protein yang masuk ke dalam intestinum berasal dari protein pakan yang tidak terdegradasi di dalam rumen, protein endogen dan protein mikroba (Verite dan Demarquilly, 1978 ; NRC, 1985). Metabolisme nitrogen di dalam rumen dapat dibagi menjadi 2 tahap yaitu degradasi protein dengan media aktivitas proteolitik mikroba dan sintesis protein mikroba di dalam rumen, yang dikendalikan oleh ketersediaan $\mathrm{N}$ terdegradasi dan energi (Verite dan Peyraud, 1988; Nocek dan Russel, 1988b). Evaluasi degradasi protein dapat dilakukan secara metode in vitro dengan mengukur kelarutannya dalam larutan buffer 
(Satter dan Slyter, 1974 ; Madsen dan Hvelplund, 1985 ; Verite dan Demarquilly, 1978), metode in vivo (Faichney, 1975 dan Zinn et al., 1980) dan metode in sacco (Orskov dan McDonald, 1979 ; MichaletDoreau et al., 1987 ; Lindberg, 1981 dan Verite et al., 1990). Dari ketiga metode evaluasi degradasi protein di atas, metode in sacco lebil sering digunakan dengan alasan lebih sederlaana dan juga secara langsung pakan diinkubasikan pada lingkungan rumen. Selain itu metode in sacco dapat dihitung kecepatan degradasi protein dalam rumen dan beberapa sampel dapat diinkubasikan pada waktu yang bersamaan.

Degradasi protein dalam rumen sangat bervariasi menurut asal dan jenis pakan, umur pemotongan, perlakuan kimia atau fisik (Zinn dan Owens, 1981 ; Madsen dan Hvelplund, 1985 ; Verite dan Demarquilly, 1978 ; Le Goffe, 1991) serta aktivitas mikroba rumen yang tergantung dari substrat dan lama tinggal pakan dalam rumen (NRC, 1985 ; Widyobroto, 1992). Selain itu taktor-faktor metodologi juga mempengaruhi degradasi protein, antara lain porositas kain nilon, ukuran partikel sampel dan perbandingan berat dengan luas permukaan kantong, perlakuan sampel, granulometri sampel, pencucian kantong setelah inkubasi Jalam rumen, ransum percobaan, variasi antar ternak, variasi antar pengukuran, spesies ternak dan metode yang digunakan untuk menghitung DT (Orskov et al., 1981 ; Lindberg, 1985 ; Nocek 1988a ; Verite ct al., 1990 ; Setala, 1985).

Penelitian ini dilakukan dengan tujuan untuk mengetalui kinetik kehilangan dan degradasi bahan orgaik dan protein lima jenis rumput tropik dengan metode in sacco.

\section{Materi dan Metode}

Penelitian ini dilakukan dengan menggunakan 3 ekor sapi Peranakan Friesien Holstein (PFH) tidak berproduksi yang difistulasi pada bagian rumennya. Ransum diberikan secara terbatas (hidup pokok), terdiri dari Pennisetum purpureun dan konsentrat dengan imbangan $70 \%$ : $30 \%$ (Tabel 1). Ransum selama periode koleksi dianalisis komposisi kimianya meliputi Abu, Serat Kasar (SK), Protein Kasar (PK), Ekstrak Ether (EE) dan Ekstrak Tanpa Nitrogen (ETN). Untuk mengetahui aktivitas fermentasi dalam rumen dilakukan pengambilan cairan rumen dan selanjutnya diukur $\mathrm{pH}$ dan $\mathrm{N}-\mathrm{NH}_{3}$ setelah distribusi pakan. Periode adaptasi terhadap ransum percobaan dilakukan selama 3 minggu, ransum didistribusikan 2 kali sehari, pagi pukul 7.00 dan sore hari pukul 17.00 dengan proporsi yang sama.

Sampel rumput Pennisetum purpureum, Panicum maximum, Setaria spacelata, Cynodon dactylon Brachiaria mutica ditanam di kebun percobaan Fakultas Peternakan Universitas Gadjah Mada, rumput Brachiaria mutica dipotong pada umur 70 hari dan empat rumput lainnya dipotong pada umur 60 hari. Kandungan PK masing-masing adalah 9,$60 ; 8,92 ; 8,41$; 14,68 dan $7,52 \%$ BK untuk Pennisetum purpureum, Panicum maximum, Setaria spacelata, Cynodon dactylon dan Brachiaria mutica. Sampel dikeringkan pada temperatur $80^{\circ} \mathrm{C}$ selama $48 \mathrm{jam}$, kemudian digiling dengan hanmer mill $1 \mathrm{~nm}$.

Kantong dibuat dari kain nilon dengan porositas $46 \mu \mathrm{m}$, dimensi bagian dalam $6 \times 11 \mathrm{~cm}$. Kantong nilon dioven pada suhu $40^{\circ} \mathrm{C}$ selama 1 jam, ditimbang satu-persatu untuk mengetahui berat kosong dan kemudiaan ditandai sesuai dengan kode pakan yang diuji, nomor sapi dan waktu inkubasi. 
Susunan ransum $(\%)$

\begin{tabular}{|c|c|}
\hline Pennisetum purpurcum & 70,0 \\
\hline Bekatu padi & 12,3 \\
\hline Cassava & 12,3 \\
\hline Bungkil kedelai & 3,0 \\
\hline Molases & 1,5 \\
\hline Urea & 0,6 \\
\hline Mineral* & 0,3 \\
\hline \multicolumn{2}{|l|}{ Komposisi kimia } \\
\hline Bahan organik $(\mathrm{g} / \mathrm{kg} \mathrm{BK})$ & 839 \\
\hline Protein kasar (g/kg BK) & 104 \\
\hline Serat kasar $(\mathrm{g} / \mathrm{kg}$ BK) & 268 \\
\hline Lenak (g/kg BK) & 26 \\
\hline Ekstrak tinpa nitrogen $(\mathrm{g} / \mathrm{kg} \mathrm{BK})$ & 453 \\
\hline Energi (kcal/kg BK) & 1.683 \\
\hline
\end{tabular}

$\mathrm{p}=\mathrm{b}$

$\mathrm{a}=\mathrm{fr}$

$\mathrm{b}=\mathrm{fr}$

$c=l a$

Cassava

12,3

3,0

1,5

0,6

varians

Cox,

Compu

1987).

dengar

$\mathrm{pH}$ da

Cuprum $0,13 \%$, Sodiun $21,0 \%$, Iron $0,82 \%$, Zine $0,20 \%$, Mugnesium $0,15 \%$ dan Chlor $1,05 \%$

Kantong diisi dengan sampel pakan yang akan diuji $(3 \mathrm{~g})$, ditautkan dengan tali nilon pada cincin besi berlapis chrom (675 g) kenudian diinkubasikan kedalam rumen dengan enam interval inkubasi yang berbeda yaitu $2,4,8,16,24$ dan 48 jam, setiap titik inkubasi diadakan 6 kali ulangan dan inkubasi dilakukan sebelum pakan pagi didistribusikan. Kantong nilon diambil dari rumen sesuai dengan waktu inkubasi, segera dicuci dengan air kran dingin yang mengalir perlahan-lahan, kemudian disimpan pada sulhu $-15^{\circ} \mathrm{C}$ atau langsung dicuci dengan mesin cuci selama 9 menit dengan air selalu mengalir (MichaletDoreau et al., 1987).

Residu pakan setelah inkubasi dikeringkan pada sulıu $80^{\circ} \mathrm{C}$ selama 48 jam kemudian masing-masing ditimbang residunya sntuk menghitung kehilangan BK. Kadar bahan kering dan kadar abu residu dideterminasi setelah pengeringan $105^{\circ} \mathrm{C}$ dan dilanjutkan pengabuan pada suhu $550^{\circ} \mathrm{C}$ (AOAC, 1980). Nitrogen dianalisis dengan metode Kjeldahl. Evolusi pH Jan kadar N$\mathrm{NH}_{3}$ cairan rumen setelah distribusi pakan diukur dengan menggunakan 2 ekor sapi pada akhir penelitian. Konsentrasi $\mathrm{NH}_{3}$ dianalisis dengan metode Conway (1962).

Data yang diperoleh berupa kehilangan BO Jan PK menurut waktu inkubasi 2, 4, 8, 16, 24, 48 jam digunakan untuk menghitung degradasi BO dan PK dengan asumsi gerak laju (kp) partikel pakan keluar rumen adalah 0.06 (Verite dan Peyraud, 1988). Dengan hipotesis bahwa laju kecernaan BO dan PK (kd) konstan terhadap waktu, diterapkan model exponensial yang diajukan oleh Orskov dan sapi y:

dilihat cairan pakan setelal Goetsc rumen besarn ransun yang d perah cairan tercap: evolus menda kisara rumen

bervar distrit minim 
McDonald (1979).

$$
\mathrm{p}=\mathrm{a}+\mathrm{b}(1-\exp (-\mathrm{ct}))
$$

$\mathrm{p}=$ bahan yang hilang pada waktu $\mathrm{t}$

$\mathrm{a}=$ fraksi mudah larut

$\mathrm{b}=$ fraksi potensial untuk terdegradasi

$c=$ laju degradasi dari fraksi $b$

$$
\mathrm{DT}=\mathrm{a}+(\mathrm{b} * \mathrm{c} / \mathrm{c}+0,06)
$$

Data degradasi BO dan PK dianalisis variansi dengan pola searah (Cochran dan Cox, 1957), menggunakan Personal Computer Statistic Analyse System (SAS, 1987). Bila terdapat perbedaan dilanjutkan dengan uji Duncan.

\section{Hasil dan Pembahasan}

pH dan Konsentrasi $\mathrm{N}-\mathrm{NH}_{3}$ Cairan Rumen

Evolusi $\mathrm{pH}$ dan $\mathrm{N}-\mathrm{NH}_{3}$ cairan rumen sapi yang menerima ransum percobaan dapat dilihat pada Gambar 1 dan Gambar 2. pH cairan rumen menurun setelah distribusi [akan dan nilai minimum tercapai 3-4 jam setetali distribusi pakan sore $(5,9)$. Owens dan Guetsch (1988) melaporkan bahwa $\mathrm{pH}$ cairan rumen berkisar antara 5,5 sampai 7,2 dan besarnya $\mathrm{pH}$ cairan rumen dipengaruhi jenis ransum. Evolusi pH cairan rumen sesuai hasil yang dilaporkan Widyobroto (1992) pada sapi perah yang diberi konsentrat $35 \%$ bahwa $\mathrm{pH}$ cairan rumen bervariasi dan $\mathrm{pH}$ minimum tercapai 3 jam setelah distribusi pakan. Hasil evolusi $\mathrm{pH}$ cairan rumen sapi perah yang mendapat ransum percobaan masih dalam kisaran optimum untuk aktivitas mikroba rumen (Kauftman et al. 1980).

Konsentrasi $\mathrm{N}-\mathrm{NH}_{3}$ cairan rumen bervariasi secara siklus dan meningkat setelab Uistribusi pakan. Konsentrasi $\mathrm{N}-\mathrm{NH}_{3}$ minimum adalah $8,8 \mathrm{~g} / 100 \mathrm{ml}$, dan masil di atas kebutuhan mikroba. Blanchari (1988) menunjukkan baliwa konsentrasi $\mathrm{N}-\mathrm{NH}_{3}$ $2,2-13,3 \mathrm{mg} / 100 \mathrm{ml}$ diperlukan untuk perkembangan mikroba rumen. Pada pengukuran degradasi secara in sacco, Mehrez dan Orskov (1977) melaporkan bahwa dengan menggunakan ransum basal hay dan konsentrat orge, peningkatan konsentrasi $\mathrm{NH}_{3}$ cairan rumen dapat meningkatkan kenaikan degradasi BK pakan dan pada konsentrasi $>23,8 \mathrm{mg} / 100 \mathrm{ml}$ tidak terjadi kenaikan lagi.

\section{Kinetik Degradasi Bahun Organik dan Protein}

Kinetik kehilangan BO dan PK rumput tertera pada Gambar 3. dan Gambar 4. Kinetik kehilangan BO dan PK meningkat sejalan dengan lama inkubasi, dan kecepatannya makin lama makin berkurang. Variasi kehilangan pada inkubasi 24 dan 48 jam sangat kecil, yaitu $0,5 \%$ dan $0,4 \%$ masing-masing untuk BO dan PK. Hasil di atas menunjukkan bahwwa persentase kehilangan setelah inkubasi 48 jam dapat dianggap nilai maksimum, sehingga sesuai dengan estimasi degradasi pada metodologi yang diterapkan yaitu 48 jam. Kelilangan BO dan PK pada 4 jam setelah inkubasi rata-rata untuk 5 rumput adalah $26,06 \%$ dan $43,03 \%$. Hasil pada penelitian ini sedikit lebiln rendah dibanding hasil yang Jilaporkan oleh Cerneau et al. (1992), 24$57 \%$ untuk BO, dan 28-45 \% untuk PK.

\section{Degradasi Bahan Organik}

Rata-rata fraksi BO mudah larut (a), fraksi BO potensial terdegradasi (b), laju degradasi fraksi b (c) dan degradasi BO dapat dilihat pada Tabel 2. Degradasi BO rumput $P p$ tertinggi $(\mathrm{P}<0,01)$ dibanding rumput lainnya $(45,13 \%)$. Hal ini dapat dijelaskan oleh tingginya fraksi BO 

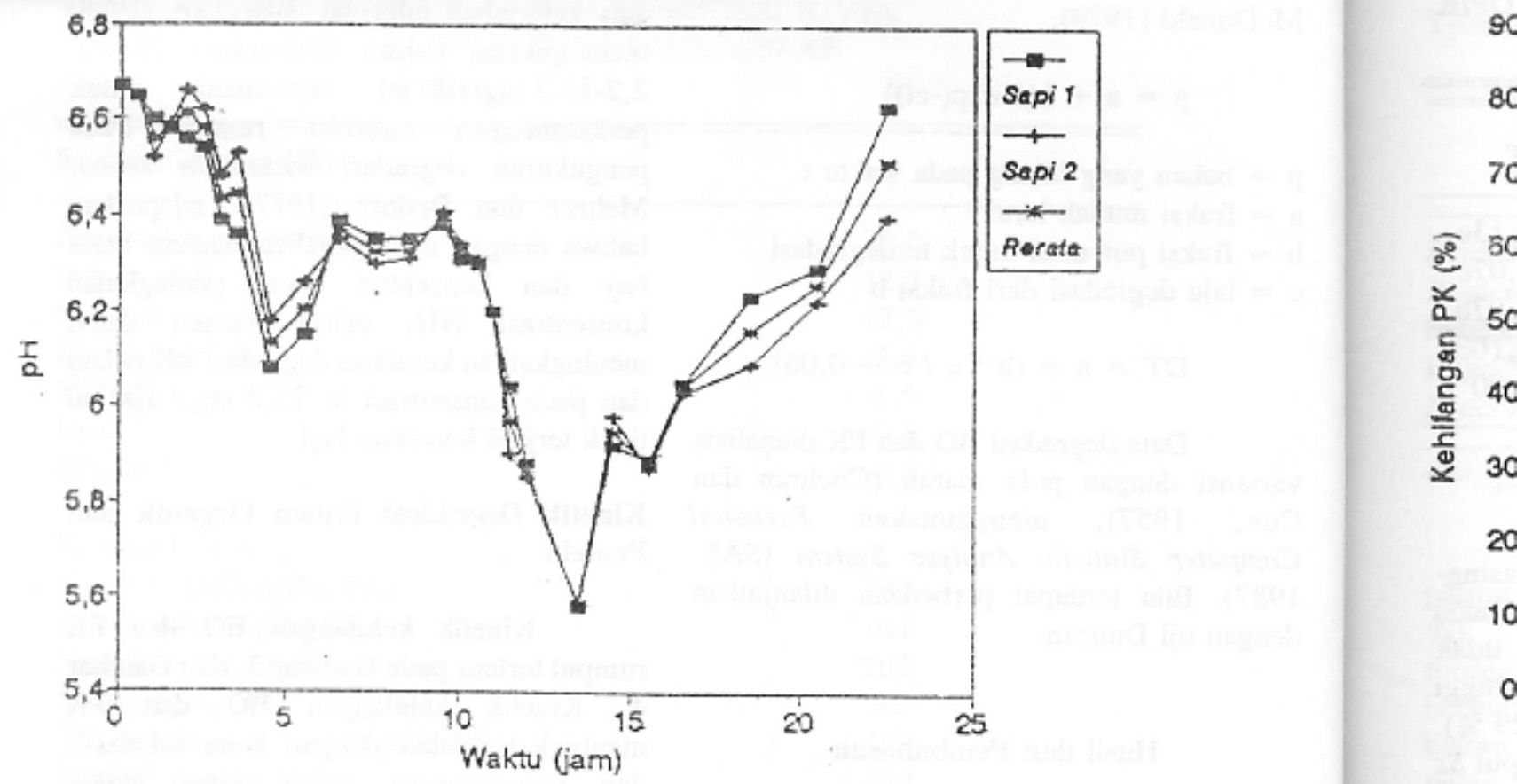

Gratik 1. Evolusi pH cairan rumen (Post feeding)

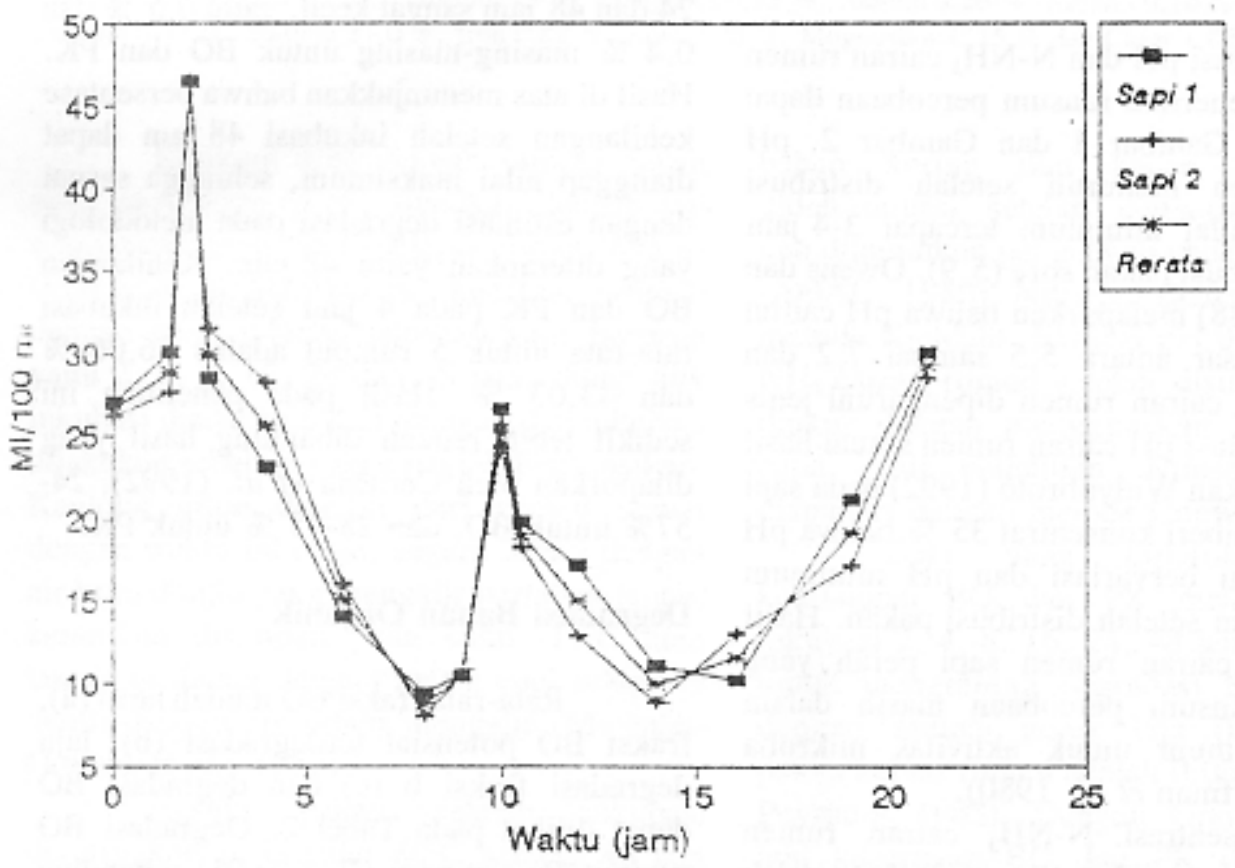

Gratik 2. Evolusi konsentrasi $\mathrm{N}-\mathrm{NH}_{3}$ cairan rumen (post feeding) 


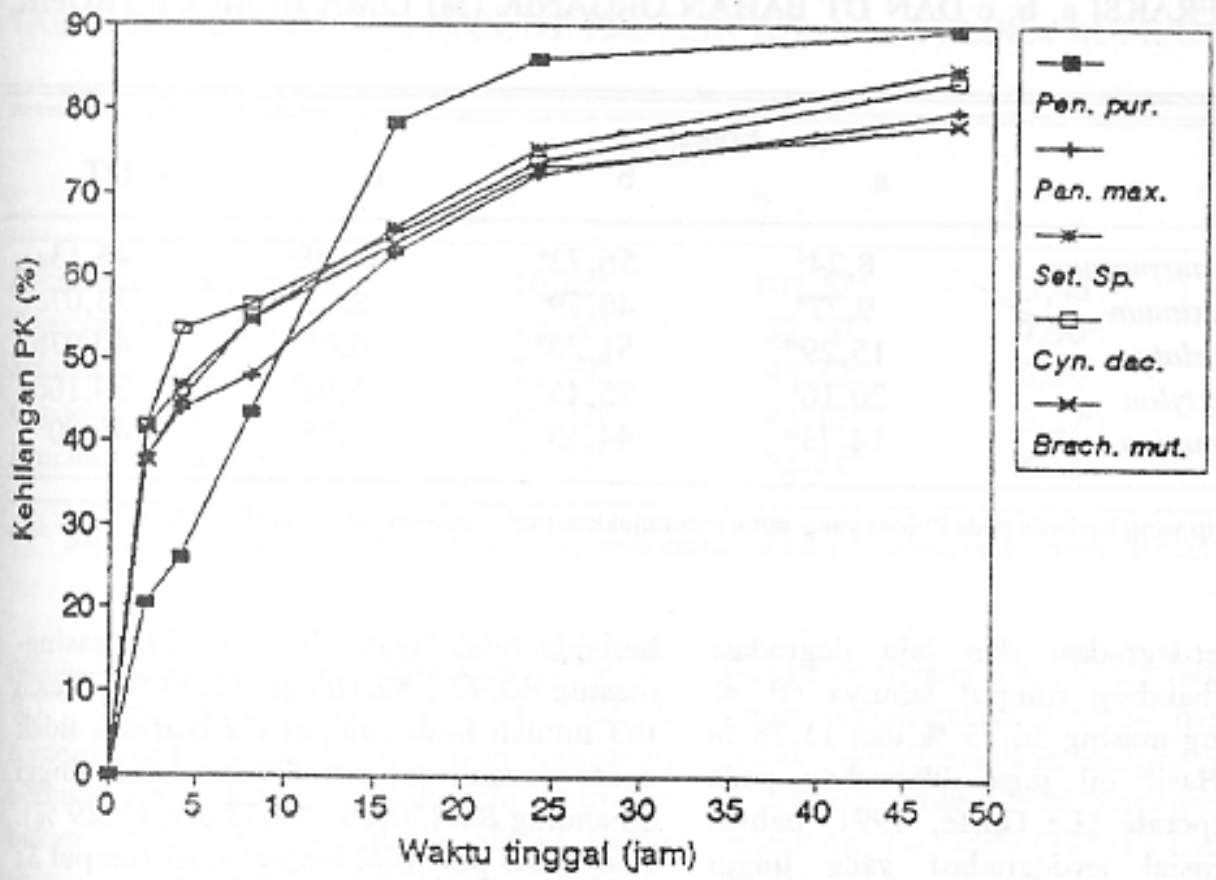

Gratik 3. Kinetik degradasi bahan organik (\%) lima jenis rumput

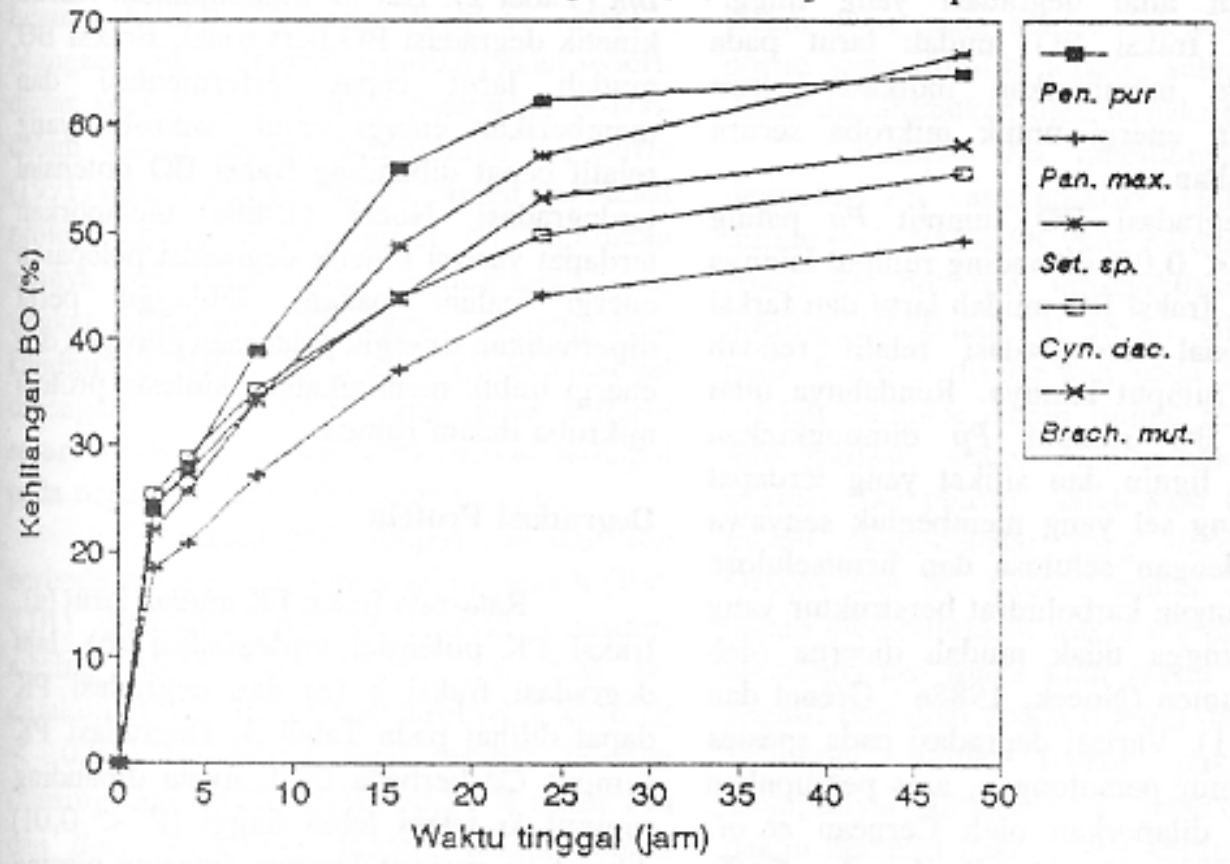

Grafik 4. Kinetik degradasi protein (\%) lima jenis rumput 


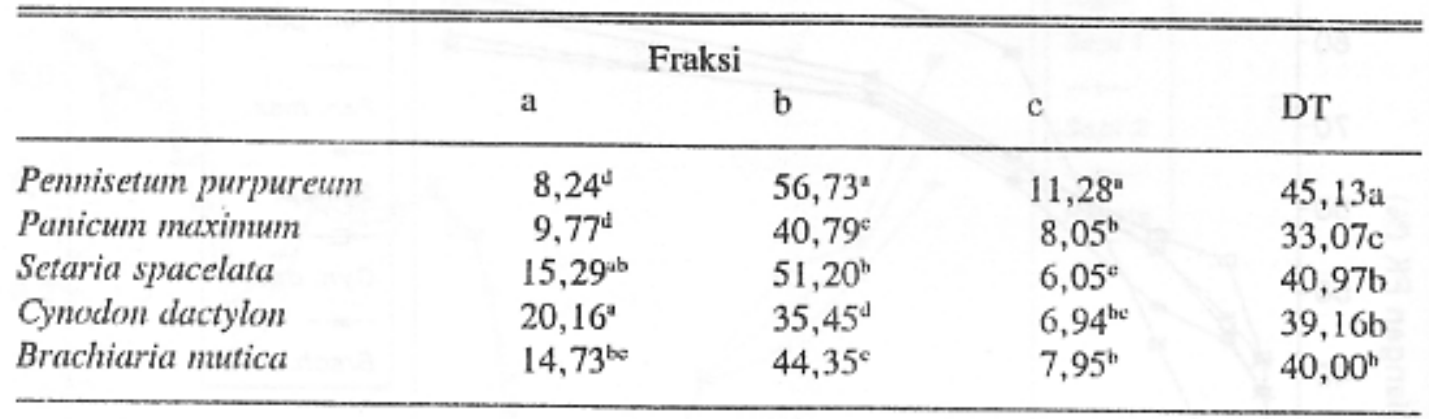

•,bes: Superskrip yang berbeda pedu kolom yang sama menunjukkun perbedaan sangat nyalu $(\mathrm{P}<0,01)$

potensial terdegradasi dan laju degradasi fraksi b dibanding rumput lainnya $(\mathrm{P}<$ 0,01 ), masing-masing $56,73 \%$ dan $11,28 \%$ per jam. Hasil ini juga dilaporkan pada rumput temperate (Le Goffe, 1991) baliwa fraksi potensial terdegradasi yang tinggi didukung dengan laju degradasi yang cepat memberikan nilai degradasi yang tinggi. Rendalnnya fraksi BO mudah larut pada rumput $P_{p}$ memberikan indikasi bahwa kelersediaan energi untuk mikroba secara perlahan-lahan.

Degradasi BO rumput $P p$ paling rendah $(P<0,01)$ dibanding rumput lainnya $(33,07 \%)$, fraksi BO mudah larut dan farksi BO potensial terdegradasi relatif rendah dibanding rumput lainnya. Rendahnya nilai degradasi BO rumput $P$ p dimungkinkan kandungan lignin dan silikat yang terdapat pada dinding sel yang membentuk senyawa komplek dengan selulosa dan hemiselulosa atau kandungan karbohidrat berstruktur yang tinggi sehingga tidak mudah dicerna oleh mikroba rumen (Nocek, 1988a ; Grenet dan Besle, 1991). Variasi degradasi pada spesies rumput, umur pemotongan, aras pemupukan juga telah dilaporkan oleh Cerneau et al. (1992) pada rumput tropik dan Le Goffe (1991) pada rumput temperate.

Degradasi BO rumput $\mathrm{Ss}, \mathrm{Cl}$ dan $\mathrm{Bm}$ berbeda tidak nyata $(\mathrm{P}>0,05)$, masingmasing 40,$97 ; 39,16$ dan 40,00\%. Fraksi BO mudah larut rumput $\mathrm{Cl}$ berbeda tidak nyata dengan rumput $S s$ dan lebil tinggi dibanding $B m(20,16 ; 14,73$ dan $15,29 \%)$. Fraksi $\mathrm{BO}$ potensial terdegradasi rumput $S s$ lebil tinggi $(\mathrm{P}<0,01)$ dibanding $\mathrm{Cl}$ dan $B m$ (Tabel 2). Hal ini menunjukkan bahwa kinetik degradasi BO bervariasi. Fraksi BO mudah larut cepat terfermentasi dan memberikan energi. untuk mikroba yang relatif cepat dibanding fraksi $\mathrm{BO}$ potensial terdegradasi. Nocek (1988a) melaporkan terdapat variasi kinetik degradasi/pelepasan energi bahan pakan, sehingga perlu diperhatikan sinergik pelepasan nitrogen dan energi untuk meningkatkan sintesis protein mikroba dalam rumen.

\section{Degradasi Protein}

Rata-rata fraksi PK mudah larut (a), fraksi PK potensial terdegradasi (b), laju degradasi fraksi b (c) dan degradasi PK dapat dilihat pada Tabel 3. Degradasi PK rumput $\mathrm{Cd}$ berbeda tidak nyata dibanding rumput $S s$ tetapi lebih tinggi $(\mathrm{P}<0,01)$ dibanding rumput lainnya (masing-masing $62,25 \%$ dan $60,78 \%$ untuk $C d$ dan $S s$ ). Fraksi PK mudah larut pada rumput $\mathrm{Cl}$
Pennise

Panicur

Setaria

Cynodo

Brachic

- s,eses: Sup

paling 1

$\%)$.

terdegr

berhubr

bukan

dalam

rumput

hijauan

Manga:

diatas

dalam

(1991)

protein

adanya

tingkat

kandun

dipeng:

secara

pada o.

berbed:

0,01 )

masing

diduku

$<0$,

(masin

dan $B$

yang

memas

sangat 
TABEL 3. FRAKSI a, b, c DAN DT PROTEIN KASAR (\%) LIMA RUMPUT TROPIK

\section{Fraksi}

a b

c

DT

Pennisetum purpureum

Panicum maximum

$-10,86^{\circ}$

$26,90^{4}$

$35,69^{\mathrm{b}}$

$40,22^{u}$

$30,51^{\mathrm{c}}$

Cynodon dactylon

Brachiaria mutica b

$101,58^{a}$

$52,70^{b}$

$49,22^{\text {be }}$

$43,13^{\circ}$

$52,81^{\text {b }}$ $13,45^{a}$

$7,90^{b}$

$6,29^{\mathrm{c}}$

$6,27^{\circ}$

$8,11^{\text {b }}$ $59,38^{b}$

$56,80^{\mathrm{c}}$

$60,78^{\text {ab }}$

$62,25^{2}$

$57,96^{\mathrm{c}}$

hest: Superskrip yang berbeda pada kolom yang sama menunjukkan perbedaan sangat nyata $(P<0,01)$

paling tinggi dibanding rumput lainnya $(40,22$ \%). Besarnya fraksi protein mudalı terdegradasi pada $\mathrm{Cl}$ dimungkinkan berhubungan dengan kandungan nitrogen bukan protein (NPN), asam amino bebas dalam protein tota! lebih tinggi dibanding rumput lainnya. Hal ini juga terjadi pada lijauan Alfalfa (Demarquilly et al., 1981; Mangan, 1982). Ingestion bahan pakan seperti diatas secara cepat diikuti pelepasan $\mathrm{N}-\mathrm{NH}_{3}$ dalam cairan rumen. Selanjutnya Le Goffe (1991) menunjukkan adanya variasi degradasi protein antara jenis rumput dimungkinkan adanya perbedaan umur pemotongan serta tingkat pemupukan sehingga mempengaruhi kandungan NPN. Degradasi protein sangat dipengaruhi oleh NPN yang dapat terlarut secara keseluruhan dan NPN banyak terdapat pada organ vegetatif dan akar tanaman.

Degradasi $\mathrm{PK}$ rumput $\mathrm{Pm}$ dan $\mathrm{Bm}$ berbeda tidak nyata, tetapi lebih rendah $(\mathrm{P}<$ 0,01 ) dibanding rumput lainnya (masingmasing 56,80 dan $57,96 \%$ ). Hal ini didukung fraksi $\mathrm{PK}$ mudah larut lebih kecil (P $<0,01$ ) dibanding tiga rumput lainnya (masing-masing 26,90 dan 30,51\% untuk $\mathrm{Pm}$ dan $B m$ ). Degradasi protein dalam rumen yang rendah sangat diharapkan untuk memasok asam amino ternaknya dan hal ini sangat diharapkan bila kandungan asam amino dan protein yang tidak terdegradasi tersebut dapat dimanfaatkan dengan baik. Hal ini perlu dikonfirmasikan dengan pengukuran kecernaan protein tidak terdegradasi dalam intestium, Le Goffe (1991) ; Cerneau et al. (1992) melaporkan balıwa protein hijauan yang tidak terdegradasi sering terikat pada fraksi serat yang sulit untuk dicerna oleh ensim yang dimiliki ternak, sehingga tidak dapat dimanfaatkan oleh ternaknya.

Rumput $P_{p}$ mempunyai kinetik degradasi PK yang spesifik. Hal ini dapat dilihat pada fraksi PK yang mudah larut dan fraksi PK potensial terdegradasi (masingmasing $-10,86$ dan $101,58 \%$ ). Nilai negatif pada fraksi a disebabkan pada rumput ini setelah inkubasi dalam rumen tidak segera terdegradasi, tetapi membutuhkan waktu inisiasi (lag phase). Salah satu kelemahan model eksponensial yang dikembangkan Orskov dan Mc Donald adalah bila bahan pakan membutuhkan waktu lag phase untuk mendegradasi maka nilai fraksi a menjadi negatif dan nilai fraksi b lebih dari $100 \%$. Sehingga untuk bahan pakan yang mempunyai karakteristik seperti ini dan pakan berserat kasar tinggi terutama pakan daerah tropik perlu dikembangkan model lain. 


\section{Kesimpulan}

Kinetik degradasi BO dan PK bervariasi diantara rumput satu dengan yang lain, hal ini menunjukkan bahwa indek ketersediaan energi dan prekursor nitrogen untuk mikroba rumen berbeda. Terdapat variasi degradasi $\mathrm{BO}$ dan $\mathrm{PK}$ pada lima jenis rumput, hal ini merupakan informasi yang penting dalam penyusunan ransum pada ternak runinansia.

\section{Ueapan Terima kasih}

Penulis mengucapkan terima kasih kepada Direktorat Pembinaan Penelitian dan Pengabdian pada Masyarakat, Direktorat Jenderal Pendidikan Tinggi Departemen Pendidikan dan Kebudayaan Republik Indonesia yang telah membiayai penelitian ini de n g a n o m e r k on trak : 044/P4M/DPPM/PHBII/1/1993 Tanggal 26 Mei 1993.

\section{Daftar Pustaka}

AOAC. 1980. Official Methods of Analysis 13 th Ed. Association of Official Analytical Chemist., Washington,DC.

Blanchart, G. 1988. Degradation des matieres azotees d'origine vegetale chez le ruminant: Explication et prevision a partir d'un fractionnement. These de Ductorat d'Etat INPL-ENSAIA. $198 \mathrm{p}$.

Cerneau, P., A. Xande and G. Aumonts. 1992. In situ degradation of four tropical forages. Resume 7 Journćes des Rucherches sur I'alimentation et Nutrition des Herbivores. 25 26 Mars 1992.

Cucliran, W. G. and G. M. Cox. 1967. Experimental Design. John Willey and Sons, New York, NY.

Conway, E.J. 1962. Microdiffusion analysis and volumetric error. Se Ed. Crosby Lockwood and Son, Londres.

Demerquilly, C., E. Grenet, J. Andrieu. 1981. Les constituants azotes des fourrages et la prevision de la valeur azotée des fourrages. In: Prevision de la valeur nutritive des aliments des ruminants., 129-154.

Fajeluncy, G.J.1975. The used of markers to partition digestion within the gastro intestinal tract of ruminant. In: McDonald, I.W., A.C.I. Warner (Ed). Digestion and metabolism in ruminant, 277-291.

Grenet, E., J.M. Besle.1991. Microbes and fibre digestion. In : Jounny, J.P. (Ed). Rumen inicrobial melabolism and runimant digestion, 107-130.

Kaufman. W., M. Hageneister, G. Dirksen. 1980. Adaptation to changes to dietary composition, level, and freyuency of feeding. in : Ruclkebusch et Thivend (Ed.,), Proce. 5th Int. Symp. Rumisant Physiol., Clermont-Fd, 587-602.

Le Guffe, P. 1991. Methodes dêtude et facteurs de variution de la degradubilité de l'azote des fourrages verts dans le rumen. Thèse Docteur de I'ENSAR, 82.

Lindberg, J. E. 1981. The effect of basal diet on the ruminal degradation of dry matter, nitrogenous compounds and cell walls in nylon bags. Roughage and cercais in various proportions. Swedish. J. agric. Res. 11:159169.

Lindberg, J. E. 1985. Estimation of rumen degradubility of feed proteins with the in saceo teclmique and various in vitro methods : a revicw. Acta. Agric. Scand. Suppl. 25, 64-97.

Madsen, J. and T. Hvelplund. 1985. Protein degradation in the rumen. A comparison between in vivo, nylon bag, in vitro and buffer measurements. Acta Agric. Scand. 103-124.

Mangan, J.L. 1982. The nitrogenous constituents of fresh forages. In: Forage protein in ruminant animal production. Ocensional publication no. 6. British Soc. An. Prod. (Edited by Thomson, D.J.. D.E. Beever aud R.G. Gunn), 24-40.

Melirez, A. Z. and E. R. Orskov. 1977. A study of the artificial fibre bag teclınique for determining the digestibility of feeds in the rumen. J. agric. Sci. Camb. 88:645-650.

Michalet-Doreau B., R. Verite and P. Clapoutot. 1987. Methodologi de mesure de la degradabilite in sacco de l'azoie des aliments dans le rumen. Bull. Tecl. CRZV Theix, INRA. 69, 5-7.

Nocek,

Nocek.

NRC.

Orskoy

Orskov

Oweris,

SAS In

Salter, 
Nooek, J. E. 1988 (a). In situ and others methods to estimute ruminal protein and energy digestibility: A Review. J. Dairy Sci. 71, 2051-2069.

Nocek, J. E. and J. B. Russel. 1988 (b). Protein and encrgy as an integrated system. Relationshipof ruminal protein and carbolnydratc availability to microbial synthesis und milk production. J. Duiry Sci. 71, 2070-2107.

NRC. 1985, Nitrogen usage for ruminant. The National Academy Seience. 86 pages.

Orskov, E. R. and I. MeDonald. 1979. The estimation of protein degradability in the runen from incubution measurements weighted utcording to rate of passage J. Agric, Sei., Camb. 92:499-503

Orskov, E. R., M. Hughes-Jures and 1. McDonald. 1981. Degrudubility of protein supplement and utilization of undegraded protein by highproducing dairy cows, in : Wharesign, Cole, D.J.A. (Ed.), Recent developments in ruminant nutrition. Butterworths, 17-23.

Owens, F.N., A.L. Guetselt. 1988. Ruminal Fermentation. in : Clurch. (Ed.), The ruminan animal digestive pliysiology und nutrition, New Jersey, Prentice Hnil, 145-17!

SAS Lustitut lne. 1987. SAS/STAT Guide for personal Computers, Version 6 Editions. SAS Institut Inc. Cary, NC, 1028 p.

Salter, L. D. and L. L. Slyter. 1974. Effect of ammonia concentration on rumen microhial protein production in vitro. Br. J. Nutr. 32:199-208.
Setala J. 1985. Aspects on the determinution of ruminal feed proteins degradation and the quality of the indegradable fedd protein in sacco. Acta. Agric. Scuad. Fintand, 53, 139-146.

Verite, R. and C. Demarquilly, 1978. Qualité des matieres azolées des aliments pour ruminants. in : La Vache Laitière, aspects génétiques, alimentaires dan pathologiques. (Elite par Journet M. e! Hoden A.). 143157.

Verite, R. and J. L. Peyraud. 1988. Nutrition Azotee, in : Alimentation des Bovins, Ovins et Caprins, 75-93.

Verite, R., B. Michalet-Doreau, F. Vedeau and P. Clapoutot. 1990. Dégradabilité en sachets des matieres azotées des aliments concentres : Standardisation de la methode ef variubilites intra et inter laturatoires Reprod. Nutr. Dévelop, 1635-1645.

Widyobrto, B. P. 1992. Influenee de la proportion el de la nature da concentre sur les sites et la dynamique de la digestion eliez la vache hmutc productrice. Thèse Docleur de I'Universite de Rennes 1.

Zinn, R. A., L.S. Bull, R.W. Henken, F.S. Bution, C. Enloww and R.W. Tucker. 1980. Apparatus for mcasuring and subsamp̧liug digests in ruminants equipped with reentrant intestinal camulas, J. Anim. Sci.. 51, 193.

Zim, R. A. and F. N. Owens, 1981. Facturs infuencingprotein digestion in rutuimants. J. Anim. Sci., 51(suppl.10):412. 